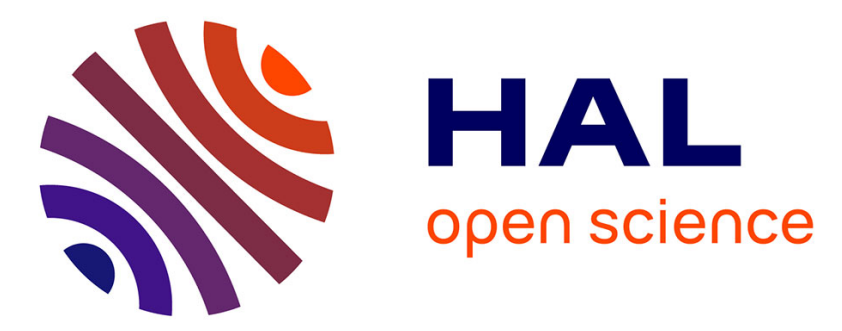

\title{
Cooperation in Real-Time Using a Virtual Environment
} Máté Köles, Károly Hercegfi, Balázs Péter Hámornik, Emma Lógó, Bálint Szabó, Anita Komlodi

\section{To cite this version:}

Máté Köles, Károly Hercegfi, Balázs Péter Hámornik, Emma Lógó, Bálint Szabó, et al.. Cooperation in Real-Time Using a Virtual Environment. 15th Human-Computer Interaction (INTERACT), Sep 2015, Bamberg, Germany. pp.461-464, 10.1007/978-3-319-22723-8_38 . hal-01610859

\section{HAL Id: hal-01610859 \\ https://hal.inria.fr/hal-01610859}

Submitted on 5 Oct 2017

HAL is a multi-disciplinary open access archive for the deposit and dissemination of scientific research documents, whether they are published or not. The documents may come from teaching and research institutions in France or abroad, or from public or private research centers.
L'archive ouverte pluridisciplinaire HAL, est destinée au dépôt et à la diffusion de documents scientifiques de niveau recherche, publiés ou non, émanant des établissements d'enseignement et de recherche français ou étrangers, des laboratoires publics ou privés. 


\title{
Cooperation in real-time using a virtual environment
}

\author{
Máté Köles ${ }^{1}$, Károly, Hercegfi ${ }^{1}$, Balázs Péter Hámornik ${ }^{1}$, Emma Lógó ${ }^{1}$, Bálint \\ Szabó $^{1}$, Anita Komlódi ${ }^{2}$ \\ ${ }^{1}$ Budapest University of Technology and Economics, Dept. of Ergonomics and Psychology, \\ Budapest, Hungary \\ \{kolesm, hercegfi,balazs.hamornik, emma, szabobalint\} derg.bme \\ . hu \\ ${ }^{2}$ University of Maryland Baltimore County, Dept. of Information Systems, Baltimore MD, \\ USA \\ komlodi@umbc.edu
}

\begin{abstract}
Effective team interaction over great distances are already supported by many digital tools. However, cooperative manipulation of common objects is limited and most non-verbal information (gaze direction, facial expressions) can be transmitted only partially or are missing completely. The inclusion of these additional information sources can enrich cooperative problems solving situations. In our demonstration we highlight the capabilities of the Virtual Collaboration Arena to support such interactions. With the help of a volunteer from the audience in Bamberg we will present parts of an information management task solved cooperatively with another user seated in Budapest.
\end{abstract}

Keywords: virtual reality, cooperation, problem solving,

\section{Introduction}

Non-verbal communication is just as important as verbally transmitted information in real world scenarios. If the social interaction takes place in a virtual world, the number of available non-verbal cues becomes limited. This is a problem, since partial or incomplete non-verbal signals can lead to misinterpretation and ultimately hinder cooperation [1]. The more sources available the easier it is to disambiguate what the other person was trying to communicate. Also having congruent signals from these different channels will increase percentage of recalled information [2] and create a more empathic feel towards the other person[3, 4].

Collaboration in virtual spaces is currently limited in conveying important non-verbal information. Since registering and virtually recreating whole body movement (including facial expression) of an individual is not cost effective at this time, compromises have to be made. A selection of easy to implement non-verbal channels should be selected to enhance communication in virtual environments. Head orientation is a powerful cue that can signal social attention [5]

Virtual environments may seem to be inherently inferior to real-life environments in case of cooperation, but that is not true for all aspects of the interaction. First of all, 
the laws of physics can be changed according to the goals of the cooperators. Inspection and theoretical modification of a heavy object for example is much easier to do in virtual space. And if the virtual space supports it, changes are instantly visible compared to a drawing on a paper. Also, some suggest that people can feel more liberated in virtual environments and express their character better than in real-life[6]. And at last but not least, geographic distances are not a problem anymore. Virtual team meetings can be held even if the members are on different continents.

\subsection{The Virtual Collaboration Arena (VirCA)}

The demonstration will feature the Virtual Collaboration Arena (VirCA) as the system responsible for the virtual environment. It is a loosely coupled, modular system capable of supporting a wide array of tasks. From remote robot control [7] through virtual meetings to psychological experiments in spatial cognition [8]. It was developed by Cognitive Informatics Research Group of the Computer and Automation Research Institute of the Hungarian Academy of Sciences. Custom rooms and objects are easy to define and use. It support classic input devices as mouse and keyboard but also gaming controllers and motion tracking.

\section{Demonstration}

\subsection{The virtual environment}

The interaction will take place in a $3 \times 3 \mathrm{~m}$ virtual room designed to represent a tourist office. It contains a map of Budapest, posters and flyers about different sights and activities and jointly editable documents (Fig. 1.). It also has a few decorative items (a plant, a trash bin and a window) to create a more natural feel.

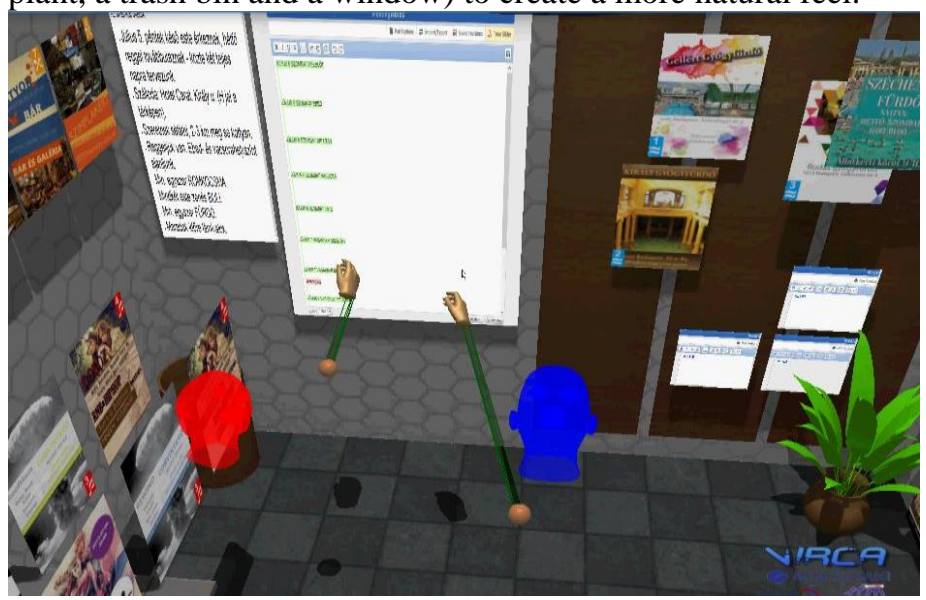

Fig. 1. The virtual environment representing a tourist office with the avatars of the users in the middle. 
The posters contain information about the location of the given activity with opening hours and entry fees (if any). They are grouped into four different categories by symbols: sights, baths, clubs and restaurants. Both participants are able to move or highlight the posters.

The editable documents serve as notepad pages, where ideas can be written down. They can also be used to add activities not represented by the available posters.

Each participant is represented by a single colored head. The reason behind the simplicity of the avatars is the following. As established in the introduction earlier, the more detailed the avatar, the more equipment and resources are required. These simple avatars are able to convey head orientation which is a very important social cue[5], pointing gestures (for clarifying common attentional objects) and also intonations through real-time voice chat.

\subsection{Brief description of the task}

The demonstration aims to replicate the first part of an information management task. There will be two phases. The training will introduce the participant and the audience in Bamberg to the virtual space and the possible forms of interaction. For the actual collaborative part of the task, we will connect live to another user situated in Budapest. From that point on, users will have to solve a task that simulates creating a holiday plan for a tourist group for a weekend at Budapest. We decided to include a few conditions that should be met by every successful solution.

The exact instructions are: "Create a holiday plan for two days for a foreign tourist group who are around your age. Make sure to include in your plan a trip to a bath and a pub. Also, both days should end at a club. Suggest places for lunch and dinner for both days; they receive breakfast at their hotel. Try to fill both days with classic tourist attractions. Create a plan that is varied, yet manageable. Display the final plan in the table located on the front wall."

The task requires participants to decide together on a plan that satisfies most criteria. The posters contain all the information required to solve the task. No existing knowledge of Budapest is required. However, there are some activities that are not available on weekends so they have to be mindful of their choices. All posters that become part of the plan should be placed in a timetable on the wall. The task will run until the plan is finished or time for the demonstration runs out. A brief evaluation of the solution is given at the end.

Acknowledgements. The present study was supported by the KTIA_AIK_12-1-20130037 project: Virtual NeuroCognitive Space for research and development of future immersive mediatechnologies (NeuroCogSpace). The project is supported by the Hungarian Government, managed by the National Development Agency/Ministry, and financed by the Research and Technology Innovation Fund. The authors thank Péter Baranyi and the 3DICC Lab of SZTAKI for organizing the project and supporting the VirCA virtual environment.

\section{References}


1. Cheshin A, Rafaeli A, Bos N (2011) Anger and happiness in virtual teams: Emotional influences of text and behavior on others' affect in the absence of non-verbal cues. Organ Behav Hum Decis Process 116:2-16. doi: 10.1016/j.obhdp.2011.06.002

2. Buisine S, Martin J-C (2007) The effects of speech-gesture cooperation in animated agents' behavior in multimedia presentations. Interact Comput 19:484-493. doi: 10.1016/j.intcom.2007.04.002

3. Ang CS, Bobrowicz A, Siriaraya P, et al. (2013) Effects of gesture-based avatarmediated communication on brainstorming and negotiation tasks among younger users. Comput Human Behav 29:1204-1211. doi: 10.1016/j.chb.2012.10.013

4. Bente G, Rüggenberg S, Krämer NC, Eschenburg F (2008) Avatar-Mediated Networking: Increasing Social Presence and Interpersonal Trust in Net-Based Collaborations. Hum Commun Res 34:287-318. doi: 10.1111/j.14682958.2008.00322.x

5. Langton SRH, Honeyman H, Tessler E (2004) The influence of head contour and nose angle on the perception of eye-gaze direction. Percept Psychophys 66:752771. doi: 10.3758/BF03194970

6. Stanilova K (2014) Survey on Verbal and Non-verbal Behaviors in Real and Virtual World. Procedia - Soc Behav Sci 114:311-316. doi: 10.1016/j.sbspro.2013.12.703

7. Galambos P, Baranyi P (2011) VirCA as Virtual Intelligent Space for RTMiddleware. IEEE/ASME Int. Conf. Adv. Intell. Mechatronics. Budapest, Hungary, pp 140-145

8. Persa G, Torok A, Galambos P, et al. (2014) Experimental framework for spatial cognition research in immersive virtual space. 2014 5th IEEE Conf. Cogn. Infocommunications. IEEE, pp 587-593 